\title{
Valsts teritorijas iegūšana un zaudēšana starptautiskajās tiesībās
}

\author{
Dr. iur. Jänis Grasis \\ Rìgas Stradiṇa universitāte, Juridiskā fakultāte, \\ Tiesību zinātñu katedra, Latvija \\ janis.grasis@rsu.lv
}

\section{Kopsavilkums}

Autors rakstā aplūko valsts teritorijas iegūšanas un zaudēšanas veidus starptautiskajās tiesībās. Šis jautājums ir kḷuvis īpaši aktuāls pēc pēdējiem notikumiem Krimā, kad Krievijas Federācija okupēja šo pussalu un vēlāk to anektēja.

Atslēgvārdi: efektīva okupācija, prettiesiska teritorijas sagrābšana, teritorijas cesija, valsts teritorija.

Jau iepriekšèjā "Socrates" numurā autors pievērsās problēmai par valsts teritorijas izmaiṇām. Pēc Jura Bojāra sniegtās definīcijas "valsts teritorija ir tā zemeslodes daḷa, kura atrodas noteiktas valsts suverenitātē, teritoriālajā virsvadībā un jurisdikcijā un kuru norobežo tās sauszemes, jūras un gaisa robežas. Valsts teritorijā ietilpst sauszeme, iekšējie un teritoriālie ūden,i, zemes dzīles zem un gaisa telpa virs tiem" [1]. F. Martenss ìpaši uzsvēris, ka "teritorija, noteiktas tautas ekskluzīvā teritoriālā virsvadība absolūti nepieciešama valsts pastāvēšanai. Bez tā valsts nevar būt starptautisko tiesību subjekts" [2].

Šajā rakstā autors apkopojis galvenos valsts teritorijas iegūšanas un zaudēšanas veidus starptautiskajās tiesībās:

1) teritorijas sagrābšanu militārā ceḷā;

2) teritorijas iegūšanu noilguma cel̦ā;

3) jaunu teritoriju atklāšanu;

4) valsts teritorijas pirkšanu un pārdošanu;

5) teritorijas brīvprātīgu cesiju;

6) teritorijas pieaugumu;

7) teritorijas iegūšanu plebiscìta ceḷā. 
Latviešu valodā par šiem jautājumiem ir rakstījis J. Bojārs [1, 296-307]; A. Fogelis savā grāmatā šos jautājumus aplūkojis ḷoti īsi [3]. Raksta mērḳis ir apskatìt teritorijas iegūšanas un zaudēšanas veidus starptautiskajās tiesībās, pievēršot īpašu uzmanību Krimas un Kaḷiņingradas jautājumam.

Teritorijas sagrābšana militārā ceḷā pasaules vēsturē ir bijis l̦oti izplatīts paṇēmiens valsts teritorijas iegūšanai. No mūsdienu starptautisko tiesību viedokḷa šis paṇēmiens var būt gan prettiesisks, gan arī tiesisks. Uzskatāms piemērs prettiesiskai teritorijas sagrābšanai ir Irākas armijas iebrukums Kuveitā 1990. gada 2. augustā. Ar naftas atradnēm bagātās valsts salīdzinoši mazās armijas pretestība tika pārvarēta ātri, un Kuveitas monarhs bija spiests pamest valsti un doties uz Saūda Arābiju. Tã laika Irākas līderis Sadams Huseins paziṇoja, ka Irākas armija iebrukusi Kuveitā, lai atbalstītu briestošo sacelšanos pret šìs valsts monarhiju. Pēc Irākas iebrukuma Kuveitā Apvienoto Nāciju Organizācijas (ANO) Drošības padome noteica ekonomiskās sankcijas pret Irāku un pien̦ēma virkni rezolūciju, kurās nosodīja Irākas rīcību. 1990. gada 29. novembrī, kad bija izsmelti visi diplomātiskie centieni noregulēt krīzi, ANO Drošības padome 1991. gada 23. februāri noteica kā pēdējo termiṇu, līdz kuram Irākas armijai jāpamet Kuveitas teritorija, un atbalstīja jebkuru nepieciešamo līdzekḷu izmantošanu starptautisko prasību izpildes veicināšanai [5]. Tikmēr ASV un Lielbritānijas vadītie starptautiskie spēki, nesagaidījuši 1991. gada 23. februāri, jau 1991. gada 17. janvārī sāka Irākas bombardēšanu, un sākās militārā operācija "Tuksneša vētra" [4].

ANO Drošības padome 1991. gada 2. martā pieņēma rezolūciju, kurā tika apstiprināti miera nosacījumi, kas paredzēja tūlītēju karadarbības pārtraukšanu, Kuveitas aneksijas atsaukšanu, Irākas masu iznīcināšanas ieroču arsenāla publiskošanu un ārvalstu gūstekṇu atbrīvošanu [6]. Pēc analogiijas prettiesiska bija Krievijas Federācijas veiktā Krimas sagrābšana; taču ANO dalībvalsts Krievija izmantoja savas veto tiesības, lai bloḳētu ANO Drošîbas padomes rezolūciju nosodījumam saistībā ar Krimas referendumu par pussalas pievienošanos Krievijai. Rezolūcijas projektu, kurā bija teikts, ka Krimā notikušā referenduma rezultāti nebūs uzskatāmi par spēkā esošiem, atbalstija 13 no 15 Drošības padomes dalībvalstīm, bet pastāvīgā padomes dalībvalsts Krievija izmantoja savas veto tiesības. Savukārt K̦ina, kurai arī ir veto tiesības, no balsojuma atturējās [7].

Tiesiska teritorijas sagrābšana ar spēku var būt tikai gadījumos, ja spēks pielietots atbilstīgi starptautiskajām tiesībām pašaizsardzības karā, sodot agresoru. Uzskatāms piemērs ir PSRS veiktā Austrumprūsijas sagrābšana pēc Otrā pasaules kara. Krievijas Federācija joprojām ir šis teritorijas îpašniece [1, 297].

Teritorijas ieguvums noilguma cel̦ā ir nevienam nepiederošas vai citas valsts teritorijas iegūšana ilgstošas okupācijas cel̦ā. Starptautisko tiesību grāmatās visbiežāk min Palmas salu lietu [8]. Lietu vienpersonīgi izlēma šķīējtiesnesis Makss Hubers, kurš noteica, ka sala pieder Nīderlandei. Viņš argumentēja, ka holandieši vairāk nekā 200 gadu îstenoja salā savu jurisdikciju, tādējādi iegūstot to noilguma ceḷā. 
Šis teritorijas iegūšanas veids šobrīd aktualizējas saistībā ar Kaḷiņingradas anklāvu Krievijas Federācijā. Sagrābjot Krimu un mēg̣inot pretendēt uz citām teritorijām Austrumukrainā, Krievija pārkāpj starptautiskos līgumus par valstu robežu neaizskaramību, un tas dod pamatu atgādināt Krievijai, ka tagadējo Kaḷiṇingradas apgabalu 1945. gadā Potsdamas konferencē Krievijai uzticēja administrēt vien uz 50 gadiem. Teorētiski Potsdamas konferences lēmumu par Kaḷininingradas statusu varētu pārskatīt šīs konferences dalībnieces - Lielbritānija un ASV. Juridiskais un politiskais pamats ir pietiekams, bet trūkst politiskās gribas [14]. Kopš 1995. gada, kad beidzās Krievijas Federācijas tiesības administrēt Austrumprūsiju, jau pagājuši divdesmit gadi. Diemžēl starpvalstu attiecībās šo jautājumu neviens nav aktualizējis, tāpēc nākotnē varēsim uzskatīt, ka Krievijas Federācija ir ieguvusi šo teritoriju ar noilgumu.

Jaunu teritoriju atklāšana vēsturiski bija vecākā un vissvarīgākā metode jaunu teritoriju iegūšanā. Kopš XVIII gadsimta starptautiskajās tiesībās sāka pieprasīt jaunatklātās teritorijas efektīvu okupāciju. F. Martenss savā grāmatā norādījis, ka "tikai efektīva okupācija okupantam rada zināmas tiesības un uzliek citām valstīm attiecīgus pienākumus" [2, 362].

Teritorijas pirkšana un pārdošana pasaules vēsturē ir bijis pietiekami populārs tiesisks teritorijas iegūšanas veids. Amerikas Savienotās Valstis pagātnē bieži izmantoja naudu jaunu teritoriju ieguvei: ASV no Francijas 1803. gadā nopirka Luiziānas štatu [9], 1819. gadā - Floridu [10], no Krievijas 1867. gadā - Aḷasku [11], no Dānijas 1916. gadā Virdžīnijas salas [12].

Brīvprātīga teritorijas cesija ir vienas valsts teritorijas nodošana citai valstij saskaṇā ar starptautisku līgumu. Uzskatāms piemērs tam ir gadījums ar Helgolandes salu, kuru 1890. gadā Anglija samainīja pret līdzīgu Vācijas teritoriju Austrumāfrikā [13].

Teritorijas iegūšana pieauguma rezultātā jeb akrēcija ir vēl viens tiesisks teritorijas iegūšanas veids. Tas notiek, pieaugot jūras vai upes krastam, un uz tā rēḳina valsts palielina savu teritoriju. Hamizalas teritorijas lietā škīinējtiesā tika risināts jautājums par 600 akru lielu teritoriju gar Riograndes upi starp Elpaso Meksikā un Teksasu ASV [15]. Šḳīējtiesas lēmums nebija ASV labvēlīgs, tāpēc ASV atteicās to pildīt. Vēlāk jau lielākā daḷa Hamizalas zemes gabala tika atdota Meksikai ar 1963. gada Hamizalas lïgumu [16].

Plebiscìta ceḷā iegūta teritorija ir vēl viens veids, kā valsts tiesiski var palielināt savu teritoriju. Pasaules vēsturē var rast daudzus piemērus, kad iedzīvotāju nobalsošanas rezultātā teritorija maina savu valstisko piederību. Pirmais valstsvīrs, kas plaši izmantoja plebiscītu, bija Napoleons. Iekarotajās teritorijās tika rīkoti plebiscīti, un tās tika pievienotas Francijai. Pāvesta pilsēta Aviṇona bija pirmā, kas 1790. gadā tika iekḷauta Francijas teritorijā [1,301]. Arī Krimas iedzīvotāji varēja izmantot savas tiesības sarīkot plebiscītu, kas būtu tiesisks veids, kā iekḷauties Krievijas Federācijā. Savukārt referendumu, ko sarīkoja Krimas varas iestādes Krievijas Federācijas bruṇoto spēku klātbūtnē, pasaules sabiedrība joprojām neatzīst [7]. 


\section{Secinājumi}

Valsts teritorijas iegūšana un zaudēšana starptautiskajās tiesībās var notikt gan tiesiski, gan prettiesiski. Prettiesiska teritorijas sagrābšana Krimā, ko veica Krievijas Federācijas bruṇotie spēki, nav uzskatāma par tiesisku teritorijas iegūšanu. Savukārt Kal̦iningradu Krievijas Federācijai bija tiesības pārvaldìt līdz 1995. gadam; tomēr pasaules sabiedrība jau 20 gadu nav mēginājusi pārskatīt šo jautājumu, tāpēc jāuzskata, ka Kaḷiṇingradas apgabals nākotnē var palikt Krievijas sastāvā ar noilgumu.

\section{Gain and Loss of State Territory under the International Law}

\section{Abstract}

The author gives overview of the legal and illegal methods how to acquire and to lose state territory. It is recognised that seizure of the Crimea by military force was illegal during the spring of 2014. The Russian Federation had the rights to manage Kaliningrad till 1995; but as the international community has not expressed any objections concerning Kaliningrad, we could presume that the Russia Federation will own this territory in the future by prescription.

Keywords: territory of the state, effective occupation, illegal seizure of the territory, cession of the territory.

\section{Literatūra}

1. Bojārs, J. Starptautiskās publiskās tiesības. I sējums. Rīga: Zvaigzne ABC, 2004, 295. lpp.

2. Martenss, F. Mūsdienu civilizēto tautu starptautiskās tiesības. I sējums. Pēterburga, 1904, 354. lpp.

3. Fogels, A. Modernās starptautiskās tiesības. Rīga: Zvaigzne ABC, 2009, 178.-179. lpp.

4. Persijas liča kara vēsture. TVNET/LTV Panorāma, 2003. gada 23. martā. Iegūts no: http:// www.tvnet.lv/zinas/latvija/310848-persijas_lica_kara_vesture [sk. 30.11.2015.]

5. ANO Drošỉbas padomes 1990. gada 29. novembra rezolūcija Nr. 678. Iegūts no: http://daccessdds-ny.un.org/doc/RESOLUTION/GEN/NR0/575/28/IMG/NR057528.pdf?OpenElement [sk. 30.11.2015.].

6. ANO Drošības padomes 1991. gada 2. marta rezolūcija Nr. 686. Iegūts no: http://daccess-ddsny.un.org/doc/RESOLUTION/GEN/NR0/596/22/IMG/NR059622.pdf?OpenElement [sk. 30.11.2015.].

7. Krievija bloḳē ANO rezolūciju par Krimas referendumu. Iegūts no: http://www.tvnet.lv/zinas/ arvalstis/501550-krievija_bloke_ano_rezoluciju_par_krimas_referendumu [sk. 01.12.2015.].

8. The Island of Palmes case (U.S. vs. Netherlands). Tribunal of the Permanent Court of Arbitration 1928. Iegūts no: http://legal.un.org/riaa/cases/vol_II/829-871.pdf [sk. 01.12.2015.]. 
Jānis Grasis. Valsts teritorijas iegūšana un zaudēšana starptautiskajās tiesībās

9. Milestones: 1801-1829. Purchase of Luisiana. Iegūts no: https://history.state.gov/milestones/1801-1829/louisiana-purchase [sk. 01.12.2015.].

10. Milestones: 1801-1829. Acquisition of Florida: Treaty of Adams-Onis (1819) and Transcontinental Treaty (1821). Iegūts no: https://history.state.gov/milestones/1801-1829/ florida [sk. 01.12.2015.].

11. Milestones: 1866-1898. Purchase of Alaska, 1867. Iegūts no: https://history.state.gov/milestones/1866-1898/alaska-purchase [sk. 01.12.2015.].

12. Purchase of the United States Virgin Islands, 1917. Iegūts no: http://2001-2009.state.gov/r/pa/ ho/time/wwi/107293.htm [sk. 01.12.2015.].

13. Marshall, A. Yokell. The treaty of Helgoland-Zanzibar: the beginning of the end for the AngloGerman friendship? (2010) Iegūts no: http://scholarship.richmond.edu/cgi/viewcontent. cgi?article $=1711 \&$ context=masters-theses [sk. 01.12.2015.].

14. Politologs: Kas atgādinās Krievijai, ka Kaḷiņingrada tai vairs nepieder? Iegūts no: http://www. tvnet.lv/zinas/viedokli/527442-politologs_kas_atgadinas_krievijai_ka_kaliningrada_tai_ vairs_nepieder/print [sk. 01.12.2015.].

15. The Chamizal Case (Mexico, United States), 15 June 1911. Reports of International Arbitral Awards. Vol. XI, p. 309-347. United Nations, 2006.

16. Chamizal Treaty of 1963. Iegūts no: http://www.los-paisanos-chamizal.com/about-lospaisanos-de-el-chamizal/chamizal-treaty-of-1963/ [sk. 01.12.2015.]. 